\title{
Bioimpedance as a tool for evaluating the body composition of suruvi (Steindachneridion scriptum)
}

\author{
E. Zaniboni-Filho ${ }^{*}$, S. Hermes-Silva ${ }^{a}$, M. Weingartner ${ }^{b}$, J. E. Jimenez ${ }^{a}$, M. R. Borba ${ }^{b}$ \\ and D. M. Fracalossic \\ ${ }^{a}$ Laboratório de Biologia e Cultivo de Peixes de Água Doce - LAPAD, Universidade Federal de Santa Catarina - UFSC, \\ Rodovia SC 406, 3532, CEP 88066-000, Lagoa do Peri, Florianópolis, SC, Brazil

 \\ BR 158, Km 07, CEP 85303-820, Passinhos, Laranjeiras do Sul, PR, Brazil \\ 'Laboratório de Nutrição de Organismos Aquáticos - LabNutri, Universidade Federal de Santa Catarina - UFSC, \\ Rodovia SC 406, 3532, CEP 88066-000, Lagoa do Peri, Florianópolis, SC, Brazil \\ *e-mail: evoy@lapad.ufsc.br
}

Received: July 21, 2014 - Accepted: October 8, 2014 - Distributed: November 30, 2015

(With 1 Figure)

\begin{abstract}
Bioelectrical impedance analysis (BIA) is regarded as an important tool for evaluating the body composition of different animals in a rapid, non-destructive, and low-cost manner. A South American fish species, Steindachneridion scriptum, known as suruvi, was selected for study in this investigation. A protocol to produce fish with different body composition was used to allow BIA to adequately predict the body composition of suruvi. The fish were fed twice each day with two different diets; a low lipid diet (8.90\%), and a high lipid diet (18.68\%). These dietary differences allowed suruvi specimens with different body compositions to be produced. The BIA readings were determined using a Quantum X Bioelectrical Body Composition Analyzer. Two readings (dorsal and ventral) were obtained for each fish. After BIA readings were obtained, the proximate composition of the fish bodies for each individual was determined. All of the study data were used to establish correlation equations between proximate analyses and BIA values. Strong correlations were found for S. scriptum. The highest correlations were obtained for the following pairs of quantities, using BIA data from dorsal readings: moisture and resistance in series $\left(\mathrm{R}^{2}=0.87\right)$; protein and resistance in series $\left(\mathrm{R}^{2}=0.87\right)$; and ash and reactance in parallel $\left(\mathrm{R}^{2}=0.82\right)$. We conclude that BIA is an effective method in determining the body composition of $S$. scriptum without sacrificing the fish. However, to expand the use of this new technology it is important to define strict BIA protocols to guarantee accurate estimates.
\end{abstract}

Keywords: BIA, bioimpedance analysis, non-destructive method, native species.

\section{Bioimpedância como ferramenta de análise da composição corporal do suruvi (Steindachneridion scriptum)}

\section{Resumo}

A análise da impedância bioelétrica (BIA) é considerada uma importante ferramenta para avaliar a composição corporal de diferentes animais de uma maneira rápida, não-destrutiva e de baixo custo. A espécie Sul-americana Steindachneridion scriptum, popularmente conhecida como suruvi, foi selecionada para este estudo. Foi utilizado um protocolo para produzir peixes com distintas composições corporais, permitindo a validação da BIA para análise adequada da composição corporal do suruvi. Os peixes foram alimentados duas vezes ao dia com duas dietas diferentes: uma de baixo teor lipídico $(8,90 \%)$ e outra de alto teor lipídico $(18,68 \%)$. Essa diferença nas dietas possibilitou a produção de indivíduos com diferentes composições corporais. As leituras da BIA foram determinadas utilizando-se o equipamento Quantum X Bioelectrical Body Composition Analyzer. Duas leituras (dorsal e ventral) foram obtidas para cada peixe. Após as leituras, para cada peixe individualmente, a composição proximal dos peixes foi determinada. Todos os dados obtidos foram utilizados para estabelecer as equações de correlação entre as análises proximais e os valores da BIA. Fortes correlações foram encontradas para S. scriptum. As maiores correlações foram obtidas para as análises dorsais a seguir: umidade e resistência em série $\left(\mathrm{R}^{2}=0,87\right)$; proteína e resistência em série $\left(\mathrm{R}^{2}=0,87\right)$; cinzas e reactância em paralelo $\left(\mathrm{R}^{2}=0,82\right)$. Pode-se concluir que o método BIA é eficiente em determinar a composição corporal do suruvi S. scriptum sem sacrificar o animal. No entanto, para expandir o uso desta nova tecnologia é necessário definir protocolos rigorosos para garantir estimativas precisas.

Palavras-chave: BIA, análise de bioimpedância, método não-destrutivo, espécies nativas. 


\section{Introduction}

Many methods are available for assessing the proximate body composition of a variety of organisms; however, the most common approaches for this type of assessment, such as chemical compositional analyses following laboratory procedures, are destructive, time-consuming and utilize noxious chemicals. Electrical impedance-based methods have traditionally been used to evaluate the lipid and non-lipid contents of many animals. In particular, total body electrical conductivity (TOBEC) and bioelectric impedance analysis (BIA) have been used to determine the body composition in Micropterus salmoides (Lacepède, 1802) (Barziza and Gatlin III, 2000), Thunnus maccoyii (Castelnau, 1872)(Willis and Hobday, 2008), Centropristis striata (Linnaeus, 1758) (Fitzhugh et al., 2010), Salvelinus fontinalis (Mitchill, 1814) (Hafs and Hartman, 2011) and S. malma (Walbaum, 1792) (Stolarski et al., 2014).

Electrical conductivity methods have been employed in the agriculture and veterinary industries as a tool for quickly, non-destructively, and economically evaluating the body compositions of different animals, including poultry (Hyánková and Szebestová, 2010), swine (Mitchell and Scholz, 2009), and cattle (Bertemes-Filho et al., 2010); however, few studies of these methods have been performed with aquatic animals, and only one study with a South American freshwater fish, in this case a hybrid species (Colossoma macropomum (Cuvier, 1816) $\times$ Piaractus brachypomus (Cuvier, 1818)) with great interests for fish farming (Andrade et al., 2014).

BIA can provide estimates of body composition by measuring the resistance and reactance of fish tissue to a low-frequency electrical current. These two electrical values are then used in calculations involving common electrical property equations to generate data that may be employed in a regression model with proximate composition measures. Resistance is proportional to the voltage of an applied current as it passes through a substance; thus, this metric measures the conductive characteristics of bodies and fluids. Therefore, resistance increases as the proportions of fat and bone content in tissue increase because fat and bone are poor conductors of electricity; by contrast, resistance decreases as the proportions of water and muscle mass content in tissue increase because water and muscle are good conductors of electricity. Reactance refers to a capacitor's opposition to alternating current; thus, this metric is a measure of cell membrane capacitance, which is related to intracellular volume and extracellular water volume. Best-fit linear models that relate BIA data to proximate composition information may be selected based on adjusted $\mathrm{R}^{2}$ values (Duncan et al., 2007). According to Cox and Hartman (2005), to validate BIA method it's important to select fish with a sufficient variation in fat masses so this parameter can be adequately predicted.

In this study, we sought to establish the BIA method as a useful tool for not only field and ecological studies with fish but also the fish farming industry; this industry could benefit from the potential to use BIA to assess the body compositions of large quantities of live fish. In particular, we attempted to establish correlations between BIA and the proximal analysis of Steindachneridion scriptum (Miranda Ribeiro, 1918), a South American catfish, known as suruvi, which is of importance to fisheries and aquaculture.

\section{Material and Methods}

\subsection{Fish and experimental conditions}

Juvenile suruvi (S. scriptum) were obtained from the hormonal induction of wild breeding stock from LAPAD/UFSC that had been captured in the upper Uruguay River basin and subsequently maintained and bred in captivity. The juvenile suruvi that were selected for the experiment were initially measured and weighed, then stocked in 1000 L fiberglass tanks in a closed recirculating system with a water renewal rate that would be equivalent to $250 \%$ of the tank capacity per day. Twenty fish per tank $(137.3 \pm 31.42 \mathrm{~g}$ and $24.5 \pm 1.87 \mathrm{~cm}$ in average mass and length, respectively, \pm Standard Deviation $( \pm$ SD $)$ ) were reared over the period of 4 months.

Water quality parameters, such as dissolved oxygen $(7.40 \pm 0.36 \mathrm{mg} / \mathrm{L})$, temperature $\left(26.2 \pm 0.66^{\circ} \mathrm{C}\right)$, $\mathrm{pH}(7.2 \pm 0.52)$, and conductivity $(611.6 \pm 3.00 \mu \mathrm{S})$, were monitored twice a day immediately prior to feeding (at 08:00 and 16:00 hours) using a YSI 550A and a YSI 63 multiparameter probes (Yellow Springs Instruments Company, OH, USA). The water's hardness (113.67 \pm 40.07$)$, total ammonia $(0.29 \pm 0.19)$ and nitrite concentrations $(0.37 \pm 0.52)$, and alkalinity $(23.0 \pm 8.63)$ were evaluated once per week using the colorimetric method (Alpha Tecnoquímica, SC, Brazil). The average water quality parameters that were observed during the feeding treatment could be considered suitable for the species.

\subsection{Experimental design}

To favor the production of fish with different body composition and, thus, to allow the establishment of a BIA model to adequately predict the body composition of suruvi, it was necessary to follow a protocol to produce relatively fat and lean fish.

In this way, fish were hand-fed twice a day (at 08:00 and 16:00 hours) until apparent satiation with two different diets, one low-lipid diet and one high-lipid diet. These two different diets were employed to guarantee that fish from the two tanks would exhibit different body composition. The diet with low lipid content was a commercial feed (SUPRA/Acqua Line, São Leopoldo, RS, Brazil; $42 \%$ crude protein (CP) and $3400 \mathrm{kcal} / \mathrm{kg}$ of gross energy), and the diet with high lipid content diet consisted of the same commercial feed supplemented with soybean oil. This supplementation was accomplished by adding $250 \mathrm{~mL}$ of soybean oil and $250 \mathrm{~mL}$ of alcohol to each $\mathrm{kg}$ of the commercial feed. After this oil-alcohol mixture was sprinkled onto the feed, the feed was air-dried for 24 hours and frozen until needed. Prior to the use of the feed, samples of both diets were subjected to proximate composition analyses in accordance with the standard procedures of the Association of Official Analytical Chemists (AOAC, 1999) (as shown in Table 1).

All individual fish from both tanks were subjected to monthly weight and length measurements to monitor fish 
condition, ensuring the production of fish with distinct body compositions. Fulton's condition factor $(\mathrm{Kn})$ was calculated for each individual to quantify the "well-being" of the fish. The fish condition was calculated using the expression $\mathrm{Kn}=\left(\mathrm{W} / \mathrm{L}^{3}\right) 100$, where $\mathrm{Kn}=$ Fulton's condition factor; $\mathrm{W}=$ total weight; and $\mathrm{L}=$ total length.

After four months of feeding treatment, when fat and lean fish could be produced, feeding was interrupted to initiate BIA procedures. Additionally, to increase the range of body condition, fish were fasted for 45 days after BIA procedures have initiated; this procedures consisted of selecting five fish per tank every 15 days during this period; so it was assumed that the first 10 fish would be in the best possible body condition, and the body condition would be decreasing with the time of fasting, so the last 10 fish would be the leanest ones.

\section{3. $B I A$ readings}

For BIA procedures, fish were selected and anesthetized with clove oil, and the individual length and weight was measured. The fish were then blot dried and placed on a nonconductive board. Resistance and reactance readings for each were immediately obtained using a Quantum X Bioelectrical Body Composition Analyzer (RJL Systems, Clinton Township, MI, USA). Dorsal and ventral readings were acquired from each fish, and the distance between the two sets of electrodes was measured at each reading (mean distance $85.9 \pm 7.0 \mathrm{~mm}( \pm \mathrm{SD}$ ) for dorsal readings and $54.0 \pm 6.1 \mathrm{~mm}$ for ventral readings). Water and room temperature were measured during BIA procedures to ensure that the examined fish successfully maintained their body temperatures.

The Quantum X Bioelectrical Body Composition Analyzer possesses two sets of subdermal needles (stainless steel, $0.40 \mathrm{~mm}$ gauge) that are spaced $1.0 \mathrm{~cm}$ apart, including one signal electrode and one detecting electrode. These needles were positioned to penetrate approximately $5 \mathrm{~mm}$ into each fish. Needles locations were determined following Cox et al. (2011). To obtain dorsal readings, one set of electrodes was placed below the anterior edge of the dorsal fin, and the second set of electrodes was placed below the center of the adipose fin. Ventral readings were obtained with one set of electrodes located below the pectoral fin and the second set of electrodes placed at the anterior edge of the anal fin.

Resistance and reactance readings were used as input for bioelectrical equations to determine resistance in series and in parallel; reactance in series and in parallel; capacitance; and impedance, following Hafs and Hartman (2011).

Table 1. The composition of the diets that were used during the experiment.

\begin{tabular}{lcccc}
\hline \multicolumn{1}{c}{ Diets } & $\begin{array}{c}\text { Moisture } \\
(\%)\end{array}$ & $\begin{array}{c}\text { Protein } \\
(\%)\end{array}$ & $\begin{array}{c}\text { Lipid } \\
(\%)\end{array}$ & $\begin{array}{c}\text { Ash } \\
(\%)\end{array}$ \\
\hline $\begin{array}{l}\text { Low-lipid } \\
\text { diet }\end{array}$ & 90.38 & 45.32 & 8.90 & 18.30 \\
$\begin{array}{l}\text { High-lipid } \\
\text { diet }\end{array}$ & 95.36 & 40.24 & 18.68 & 15.81 \\
\hline
\end{tabular}

Results based on examinations of $100 \%$ dry matter.

\subsection{Body composition analysis}

After BIA readings were obtained, each fish was euthanized with an overdose of clove oil, identified, and stored $\left(-80^{\circ} \mathrm{C}\right)$ for proximate analyses. Whole body composition analyses of individual fish were conducted using the same procedures that were adopted for dietary analyses, including determinations of moisture, crude protein, crude fat, and ash (AOAC, 1999).

\subsection{Statistical analysis}

Weight gain $(\mathrm{g})$, length gain $(\mathrm{cm})$, and $\mathrm{Kn}$ were evaluated using t-tests (with a significance threshold of $\mathrm{p}<0.05$ ) to compare the growth performances of the examined fish that were subjected to the two treatments (low- and high-lipid diets).

Linear regression analyses were employed to construct BIA models by relating all of the BIA data to the data from proximate body composition analyses. Fish from the two tanks were included for BIA model development, and it is important to emphasize that to run these analyses each fish was considered an experimental unit. The models with the best fit based on adjusted $\mathrm{R}^{2}$ values were selected. Statistical analyses were performed using the software STATISTICA 7.0.

\section{Results}

The Kn of fish that experienced the two dietary treatments were similar during the first two months of feeding treatment, whereas in the third and fourth months, the Kn of fish that received a high-lipid diet were higher than the $\mathrm{Kn}$ of fish that received a low-lipid diet by a statistically significant margin ( $p<0.05$; see Figure 1), showing that fat and lean fish were produced and BIA procedures could be initiated.

Besides that, the treatments used for the suruvi (S. scriptum) (low- and high-lipid diet) allowed fish to present a great variation in body composition, creating a high amplitude of body composition to perform BIA analysis (see Table 2) and, thus, increasing the reliability of

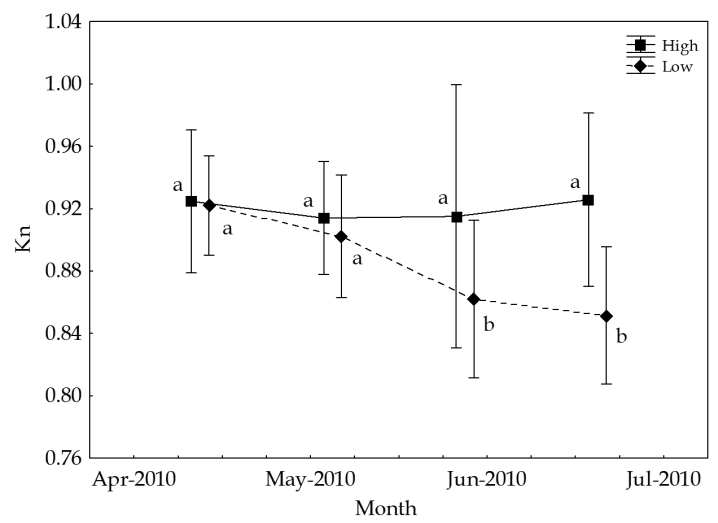

Figure 1. Condition factor (Kn) for suruvi (Steindachneridion scriptum) that were fed on low- and high-lipid diets. Different letters in the same month indicate a statistical difference. 
Table 2. Body weight and composition (\%) of individuals used for BIA analyses $(\mathrm{N}=10)$. Ranges of values (min.-max.) are presented for body weight and each parameter of body composition (moisture, protein, lipid and ash) during BIA procedures.

\begin{tabular}{cccccc}
\hline Days & Weight (g) & Moisture (\%) & Protein (\%) & Lipid (\%) & Ash (\%) \\
\hline 0 & $178.84-227.68$ & $61.76-72.59$ & $16.68-18.52$ & $4.21-11.37$ & $3.68-5.07$ \\
15 & $131.45-170.60$ & $65.16-73.61$ & $17.30-20.68$ & $2.94-9.41$ & $4.19-5.05$ \\
30 & $104.52-177.30$ & $70.08-75.73$ & $16.78-19.81$ & $2.04-7.74$ & $4.06-4.49$ \\
45 & $116.41-161.72$ & $71.36-75.47$ & $16.95-18.50$ & $1.58-5.79$ & $4.16-4.50$ \\
\hline
\end{tabular}

Day 0 represent the first BIA reading, which was done every 15 days.

the BIA method for this species. As shown in Table 2, fish weight varied from 229.8 to $104.5 \mathrm{~g}$ during BIA procedures.

During BIA procedures, the average room temperature was $22.7^{\circ} \mathrm{C} \pm 2.4( \pm \mathrm{SD})$, and the mean water temperature was $25.9^{\circ} \mathrm{C} \pm 1.0( \pm \mathrm{SD})$.

Strong correlations (high $\mathrm{R}^{2}$ values) were found between the BIA data and body composition data for $S$. scriptum. The best correlation results were obtained for the following pairs of measurements, using BIA data from dorsal readings: moisture and resistance in series $\left(\mathrm{R}^{2}=0.87\right)$; protein and resistance in series $\left(\mathrm{R}^{2}=0.87\right)$; and ash and reactance in parallel $\left(\mathrm{R}^{2}=0.82\right)($ see Table 3$)$. Poor correlations between BIA data and lipid content were observed $\left(\mathrm{R}^{2}<0.44\right)$. Ventral readings also presented poor correlations for all of the analyses, including moisture $\left(\mathrm{R}^{2}<0.48\right)$, protein $\left(\mathrm{R}^{2}<0.38\right)$, lipid $\left(\mathrm{R}^{2}<0.10\right)$, and ash $\left(\mathrm{R}^{2}<0.51\right)$.

\section{Discussion}

The high correlations that were obtained between BIA measurements and the protein, moisture, and body ash content of $S$. scriptum indicate that body composition is highly predictable by BIA approaches $\left(\mathrm{R}^{2}>0.80\right)$ and that the main objective of our study was achieved. However, dorsal BIA readings produced more accurate results than ventral BIA readings with respect to the body composition of S. scriptum. Similar results were observed by Hafs and Hartman (2011), who determinate that one of the best BIA correlations for percent dry weight of $S$. fontinalis were obtained by placing the electrodes along the dorsal midline. As suggested by Cox et al. (2011), a shift of electrodes from the dorsal side to the ventral side of a fish changes not only the distances between electrodes but also the types of tissue that are examined. According to Geddes and Baker (1967), different impedance values have been consistently reported for different tissue types. The dorsal side of a fish is primarily muscle, whereas the ventral side of a fish consists of peritoneal tissue and organs (Cox et al., 2011). The main challenge for the use of BIA measurement to determine body composition is to recognize the body region of the fish that can be utilized to obtain BIA measurements that will best correspond to overall fish body composition. In our study, the dorsal side appeared to be the best region for obtaining BIA measurements that indicate the body composition of S. scriptum.

Poor correlations between BIA measurements and lipid content have been frequently observed in other fish species,
Table 3. Equations to predict the body composition of the suruvi, S. scriptum, using the BIA method with dorsal measurements $(\mathrm{N}=40)$.

\begin{tabular}{ccccc}
\hline Component & Slope & Intercept & $\mathbf{X}$ & $\mathbf{p}$ \\
\hline Moisture & 4.22 & 8.07 & $\mathrm{R}$ in series & $* * *$ \\
Protein & 1.06 & 2.32 & $\mathrm{R}$ in series & $* * *$ \\
Ash & 1.11 & 0.45 & $\begin{array}{c}\text { Xc in } \\
\text { parallel }\end{array}$ & $* * *$ \\
& & \multicolumn{3}{c}{} \\
\hline
\end{tabular}

$\mathrm{R}=$ resistance. $\mathrm{Xc}=$ reactance. $* * * p<0.001$.

such as S. fontinalis (Cox and Hartman, 2005), Rachycentron canadum (Linnaeus, 1766) (Duncan et al., 2007) and Salmo salar (Linnaeus, 1758) (Caldarone et al., 2012). According to Cox and Hartman (2005), these poor correlations may be explained in terms of electrical resistivity. Fat mass exhibits a higher resistance than other types of tissues; in accordance with electrical rules, current will pass through all parts of a complete circuit, but more current will traverse pathways of low resistance. Thus, Cox and Hartman (2005) argue that fish fat deposits are concentrated in the ventral gut region and that these deposits demonstrate a higher electric resistance than other visceral or somatic tissues.

The potential use of BIA measurements to estimate the body composition of live fish over time, both in marine (Willis and Hobday, 2008) and freshwater fish (Andrade et al., 2014), could provide benefits for both scientists and fish farmers. In the context of fisheries, for instance, BIA measurements could be used to evaluate the nutritional status of a certain population of $S$. scriptum in different environments or along the years. Changes in the body composition of fish may compromise growth, gonadal maturation, fecundity, and the survival of offspring, compromising recruitment, and endangering an entire fish population (Ludsin and DeVries, 1997; Zaniboni-Filho and Nuñer, 2004). Conventional tools to evaluate the physiological condition of a fish stock, such as relative weight, may be highly inaccurate, and these inaccuracies may affect the interpretations of results (Copeland et al., 2008). Accurate evaluations of the physiological condition of a fish population are essential for planning efficient management actions to preserve fish stocks (Helfman, 2007).

Moreover, BIA approaches could be useful to prepare fish juveniles for stocking programs because BIA measurements can be used to monitor fish juveniles during their growth processes and ensure that these juveniles are nutritionally prepared to survive in their new environments. 
In the fish farming industry, BIA measurements could be used by farmers to help monitor the quality of the fish that are sent to market, allowing these farmers to select fish for a specific product destination, such as smoked foodstuffs; fresh or frozen fish products; or the sushi/sashimi trade. Each market product will involve specific demands with respect to the quality of the processed fish flesh, and these characteristics might be specified by various food industries.

Besides that, BIA values indicate changes in body composition during reproductive cycle of Lopholatilus chameleonticeps (Goode \& Bean, 1879) and in reproductive condition of $C$. striata individuals along the time (Fitzhugh et al., 2010; Wuenschel et al., 2013). In this way, BIA approaches can be used to select fish from broodstocks for hormonal injections that induce final maturation. The effects of body composition variations on the efficiency of hormonal treatments are well known (Zaniboni-Filho and Nuñer, 2004; Arias-Castellanos et al., 2005).

BIA has already been used to successfully determine the body compositions of different fish species (Cox and Hartman, 2005; Duncan, 2008; Andrade et al., 2014), although certain authors have argued that improvements remain necessary before BIA approaches can become a useful tool for fish farming (Bosworth and Wolters, 2001; Pothoven et al., 2008). We note that particular care (regarding room temperature and the position of needles, for instance) is required during BIA readings to minimize errors. Cox et al. (2011) suggested that the use of a strict protocol could help avoid sources of error during BIA measurements and thereby provide accurate and precise BIA estimates for field or laboratory use.

\section{Conclusions}

Our study demonstrated that BIA is effective in determining the body composition of S. scriptum without sacrificing the fish, mainly moisture, protein, and ash, although not all the parameters were able to be determinate. To expand the use of this new technology, it is necessary not only to validate and calibrate the method to other fish species but also to define strict BIA protocols to guarantee accurate estimates.

\section{Acknowledgements}

The authors would like to thank Coordenação de Aperfeiçoamento de Pessoal de Nível Superior (CAPES) and Conselho Nacional de Desenvolvimento Científico e Tecnológico (CNPq), both of the Brazilian Federal Government, for some scholarships and productivity grants provided to the authors. This project was funded by $\mathrm{CNPq}$.

\section{References}

ANDRADE, F.T., ABREU, M.L.T., LOPES, J.P., FIGUEIREDO, A.V., ARARIPE, M.N.B.A. and FERREIRA, A.H.C., 2014. Ichthyometry and electrical bioimpedance analysis to estimate the body composition of tambatinga. Acta Amazonica, vol. 44, no. 2, pp. 279-286. http://dx.doi.org/10.1590/S0044-59672014000200014.
ARIAS-CASTELLANOS, J.A., ZANIBONI-FILHO, E., PARDOCARRASCO, S.C., VÁSQUEZ-TORRES, W. and ATENCIOGARCÍA, V.J., 2005. Effect of food restriction in spawning of yamú females Brycon siebenthalae (Osteichthyes, Characidae). Acta Scientiarum, vol. 27, no. 2, pp. 235-239.

ASSOCIATION OF OFFICIAL ANALYTICAL CHEMISTS AOAC, 1999. Official methods of analysis. 16th ed. Washington, D.C.: AOAC. 1141 p.

BARZIZA, D.E. and GATLIN III, D.M., 2000. An evaluation of total body electrical conductivity to estimate body composition of largemouth bass, Micropterus salmoides. Aquatic Living Resources, vol. 13, no. 6, pp. 439-447. http://dx.doi.org/10.1016/ S0990-7440(00)01091-3.

BERTEMES-FILHO, P., VALICHESKI, R., PEREIRA, R.M. and PATERNO, A.S., 2010. Bioelectrical impedance analysis for bovine milk: preliminary results. Journal of Physics: Conference Series, vol. 224, no. 1, pp. 1-4. http://dx.doi.org/10.1088/1742$6596 / 224 / 1 / 012133$.

BOSWORTH, B.G. and WOLTERS, W.R., 2001. Evaluation of bioeletric impedance to predict carcass yield, carcass composition, and fillet composition in farm-raised catfish. Journal of the World Aquaculture Society, vol. 32, no. 1, pp. 72-78. http://dx.doi. org/10.1111/j.1749-7345.2001.tb00924.x.

CALDARONE, E.M., MACLEAN, S.A. and SHARACK, B., 2012. Evaluation of bioelectrical impedance analysis and Fulton's condition factor as nonlethal techniques for estimating short-term responses in postsmolt Atlantic salmon (Salmo salar) to food availability. Fish Bulletin, vol. 110, no. 2, pp. 257-270.

COPELAND, T., MURPHY, B.R. and NEY, J.J., 2008. Interpretation or relative weight in three populations of wild bluegills: A cautionary tale. North American Journal of Fisheries Management, vol. 28, no. 2, pp. 368-377. http://dx.doi.org/10.1577/M05-171.1.

COX, M.K. and HARTMAN, K.J., 2005. Nonlethal estimation of proximate composition in fish. Canadian Journal of Fisheries and Aquatic Sciences, vol. 62, no. 2, pp. 269-275. http://dx.doi. org/10.1139/f04-180.

COX, M.K., HEINTZ, R. and HARTMAN, K., 2011. Measurements of resistance and reactance in fish with the use of bioelectrical impedance analysis: sources of error. Fish Bulletin, vol. 109, pp. 34-47.

DUNCAN, M., CRAIG, S.R., LUNGER, A.N., KUHN, D.D., SALZE, G. and MCLEAN, E., 2007. Bioimpedance assessment of body composition in cobia (Rachycentron canadum). Aquaculture (Amsterdam, Netherlands), vol. 271, no. 1-4, pp. 432-438. http:// dx.doi.org/10.1016/j.aquaculture.2007.06.002.

DUNCAN, M.B., 2008. The use of BIA for estimating the body composition of various fish species. Blacksburg: Virginia Polytechnic Institute and State University, 74 p. Master Dissertation in Fisheries and Wildlife Science.

FITZHUGH, G.R., WUENSCHEL, M.J. and MCBRID, R.S., 2010. Evaluation of bioelectrical impedance analysis (BIA) to measure condition and energy allocated to reproduction in marine fishes. Journal of Physics: Conference Series, vol. 224, no. 1, pp. 1-4. http://dx.doi.org/10.1088/1742-6596/224/1/012137.

GEDDES, L.A. and BAKER, L.E., 1967. The specific resistance of biological material: a compendium of data for the biomedical engineer and physiologist. Medical \& Biological Engineering, vol. 5, no. 3, pp. 271-293. http://dx.doi.org/10.1007/BF02474537. PMid:6068939. 
HAFS, A.W. and HARTMAN, K.J., 2011. Influence of electrode type and location upon bioelectrical impedance analysis measurements of brook trout. Transactions of the American Fisheries Society, vol. 140, no. 5, pp. 1290-1297. http://dx.doi.org/10.1080/0002 8487.2011.620482.

HELFMAN, G.S., 2007. Fish conservation: a guide to understanding and restoring global aquatic biodiversity and fisheries resource. Washington, D.C.: Island Press. 584 p.

HYÁNKOVÁ, L. and SZEBESTOVÁ, Z., 2010. Prediction of body composition by total body electrical conductivity technique is affected by fat reserves of Japanese quail. Poultry Science, vol. 89 , no. 11, pp. 2506-2513. http://dx.doi.org/10.3382/ps.200900370. PMid:20952716.

LUDSIN, S.A. and DEVRIES, D.R., 1997. First-year recruitment of largemouth bass: the interdependency of early life stages. Ecological Applications, vol. 7, no. 3, pp. 1024-1038. http://dx.doi. org/10.1890/1051-0761(1997)007[1024:FYROLB]2.0.CO;2.

MITCHELL, A.D. and SCHOLZ, A.M., 2009. Relationships among dual-energy X-ray absorptiometry, bioelectrical impedance and ultrasound measurements of body composition of swine. Archiv fur Tierzucht, vol. 52, no. 1, pp. 28-39.

POTHOVEN, S.A., LUDSIN, S.A., HÖÖK, T.O., FANSLOW, D.L., MASON, D.M., COLLINGSWORTH, P.D. and VAN TASSELL, J.J., 2008. Reliability of bioelectrical impedance analysis for estimating whole-fish energy density and percent of lipids. Transactions of the American Fisheries Society, vol. 137, no. 5, pp. 1519-1529. http://dx.doi.org/10.1577/T07-185.1.

STOLARSKI, J.T., MARGRAF, F.J., CARLSON, J.G. and SUTTON, T.M., 2014. Lipid and moisture content modeling of amphidromous dolly varden using bioelectrical impedance analysis. North American Journal of Fisheries Management, vol. 34, no. 3, pp. 471-481. http://dx.doi.org/10.1080/02755947.2014.880764.

WILLIS, J. and HOBDAY, A.J., 2008. Application of bioelectrical impedance analysis as a method for estimating composition and metabolic condition of southern Bluefin tuna (Thunnus maccoyii) during conventional tagging. Fisheries Research, vol. 93, no. 1-2, pp. 64-71. http://dx.doi.org/10.1016/j.fishres.2008.02.010.

WUENSCHEL, M.J., MCBRIDE, R.S. and FITZHUGH, G.R., 2013. Relations between total gonad energy and physiological measures of condition in the period leading up to spawning: results of a laboratory experiment on black sea bass (Centropristis striata). Fisheries Research, vol. 138, pp. 110-119. http://dx.doi. org/10.1016/j.fishres.2012.05.012.

ZANIBONI-FILHO, E. and NUÑER, APO., 2004. Fisiologia da reprodução e propagação artificial dos peixes. In: J.E.P. CYRINO, E.C. URBINATI, D.M. FRACALOSSI and N. CASTAGNOLLI, eds. Tópicos especiais em piscicultura de água doce tropical intensiva. São Paulo: TecArt, pp. 45-73. 